УДК 582.542.2:581.961+57.063.7(470+571)

\title{
Carex delongii (Cyperaceae), a new sedge from Russia
}

\author{
I. N. Shekhovtsova ${ }^{1,4 *}$, N. N. Lashchinskiy ${ }^{1,5}$, S. V. Shekhovtsov" ${ }^{2,3}$ \\ ${ }^{1}$ Central Siberian Botanical Garden of the Siberian Branch of the Russian Academy of Sciences, Zolotodolinskaya Str., 101, \\ Novosibirsk, 630090, Russian Federation \\ ${ }^{2}$ Kurchatov Genomic Center, Institute of Cytology and Genetics of the Siberian Branch of the Russian Academy of Sciences, \\ Academika Lavrentyeva Pr., 10, Novosibirsk, 630090, Russian Federation. ORCID iD: https://orcid.org/0000-0001-5604-5601 \\ ${ }^{3}$ Institute of Biological Problems of the North of the Far Eastern Branch of the Russian Academy of Sciences, Portovaya Str., 18, \\ Magadan, 685000, Russian Federation \\ ${ }^{4}$ E-mail: maklakovain@mail.ru; ORCID iD: https://orcid.org/0000-0002-6183-3650 \\ ${ }^{5}$ ORCID iD: https://orcid.org/0000-0002-4196-7619 \\ * Corresponding author
}

Keywords: Carex, ETS, Lena River delta, matK, new species, Republic of Sakha, Yakutia.

Summary. While performing vegetation surveys in the southern part of the Lena delta, a new species of Carex from section Phacocystis has been found. Morphologically, Carex delongii sp. nov. is most close to C. cespitosa and C. minuta but differs from the former in smaller inflorescences, shorter pistillate spikes, narrow and soft leaves, oblong-ovoid (vs. ovoid) utricles; from the latter, it is distinguished by having smaller spikes and larger utricles. This relationship is also confirmed by molecular data. A detailed description of Carex delongii, its comparison with related species, illustrations, characteristics of habitat and phylogenetic position are reported.

\section{Carex delongii (Суреraceae) - новый вид из России}

\author{
И. Н. Шеховцова ${ }^{1}$, Н. Н. Лащинский ${ }^{1}$, С. В. Шеховцов ${ }^{2,3}$ \\ ${ }^{1}$ Центральный сибирский ботанический сад СО РАН, ул. Золотодолинская, 101, г. Новосибирск, 630090, Россия \\ ${ }^{2}$ Курчатовский геномный цеентр, Институт циитологии и генетики СО РАН, \\ просп. Академика Лаврентьева, 10, г. Новосибирск, 630090, Россия \\ ${ }^{3}$ Институт биологических проблем Севера ДВО РАН, ул. Портовая, 18, г. Магадан, 685000, Россия
}

Ключевые слова: дельта р. Лены, новый вид, осока, Республика Саха, Якутия, ETS, matK.

Аннотация. В работе описывается новый вид из секции Phacocystis, выявленный при изучении растительности южной части дельты реки Лены. Морфологически Carex delongii sp. nov. наиболее близок к C. cespitosa и C. minuta, но отличается от первого меньшими размерами соцветий, более короткими женскими колосками, узкими и мягкими листьями, продолговато-яйцевидными (а не яйцевидными) мешочками, а от второго - более короткими колосками и бо́льшими мешочками; выявленное родство подтвердилось молекулярным анализом. Приводится подробное описание, диагноз, иллюстрации, характеристика места произрастания, а также филогенетическое положение нового вида. 


\section{Introduction}

Carex L. (about 2000 species) is the largest genus in the family Cyperaceae (Govaerts et al., 2020). Carex section Phacocystis Dumort. is one of the most diverse and taxonomically complex groups of sedges (Egorova, 1999; Benítez-Benítez et al., 2021). There are about 116 to 147 species and subspecies of this section in the world (BenitezBenítez et al., 2021), 24 of them found in Asian Russia (Shekhovtsova, 2012).

During the vegetation surveys of 2017 to 2019 in the southern part of the Lena River delta we found a few unusual specimens of Carex from section Phacocystis on three neighboring islands: ArgaBilir-Aryta, Kurungnakh, and Samoylov. Here we describe these specimens as a new species.

\section{Materials and methods}

Morphological description of the new species is based on live (from nature) and herbarium specimens. We examined in detail the morphology of our specimens and closely related species of the section Phacocystis from the LE, MW, NS, NSK, and TK herbaria and reviewed the relevant literature (Hultén, 1968; Malyschev, 1990; Egorova, 1999; Standley et al., 2002). We also performed sequencing of the new species with its close relatives, C. cespitosa L. from Yakutia and C. minuta Franch. from the Khabarovsk Territory, as well as with the species of the section Phacocystis from GenBank.

DNA extraction was performed from $100 \mathrm{mg}$ of leaf tissue taken from the herbarium samples as described in Shekhovtsov et al. (2012). We amplified and sequenced the matK and ETS loci using universal primers taken from Starr et al. (2003) and Shekhovtsov et al. (2012). The obtained sequences were submitted to GenBank under accession numbers MZ197172-MZ197177. We compared the obtained sequences with those of several species of the section Phacocystis from the northern Palearctic. Phylogenetic trees were constructed using the Maximum Likelihood and Minimum Evolution algorithms. Maximum Likelihood analysis was performed using RAxML v. 8 with the GTR $+\mathrm{I}+\mathrm{G}$ model (Stamatakis, 2014). Minimum Evolution trees were built with the Kimura-2-parameter model, and Maximum Parsimony, with the Subtreepruning-regraphing search method, using Mega X (Kumar et al., 2018). In all cases, 1000 bootstrap replicates were performed.
Carex delongii Shekhovts. et Lashchinskiy, sp. nov. (Fig. 1).

Type: "Russian Federation, Sakha Republic (Yakutia), Bulunsky district, Kurungnakh Island, a floodplain along the Olenekskaya channel, $20 \mathrm{~m}$ from river bank, $\mathrm{N} 72.35511^{\circ}, \mathrm{E} 126.32572^{\circ}$, pioneer plant community. 26 VII 2018. N. N. Lashchinskiy" (NSK: NSK0000905; iso - NSK: NSK0000906).

Paratypes: "Russian Federation, Sakha Republic (Yakutia), Bulunsky district: Arga-Bilir-Aryta Island, floodplain along the Bolshaya Tumatskaya channel, $50 \mathrm{~m}$ from river bank, N72.39954 ${ }^{\circ}$, E126.37525 $5^{\circ}$, pioneer plant community. 15 VIII 2017. N. N. Lashchinskiy" (NSK0000917); "Kurungnakh Island, floodplain along the Olenekskaya channel, $20 \mathrm{~m}$ from river bank, N72.35511 ${ }^{\circ}$, E126.32572 ${ }^{\circ}$, pioneer plant community. 26 VII 2018. N. N. Lashchinskiy" (NSK0000918); "Samoylov Island, floodplain along the Olenekskaya channel on a distance $80 \mathrm{~m}$ from river bank, N72.37000, E126.51685', pioneer plant community. 21 VII 2019, N. N. Lashchinskiy" (NSK0000919); "Delta of the Lena River, mainland shore of the Olenekskaya channel, near Chai-Tumus town, low sand terrace, 7 VII 1956, T. Polozova, B. Yurtsev" (LE01082047).

Diagnosis. The new species belongs to the section Phacocystis, subsection Caespitosae Fries ex Kük. C. delongii differs from C. cespitosa by having smaller inflorescences, shorter pistillate spikes, narrow and soft leaves, oblong-ovoid utricles vs. ovoid in C. cespitosa. The new species differs from C. minuta by having smaller spikes: staminate spike is $0.8-1.5 \mathrm{~cm}$ long vs. to $1.5-4$ in C. minuta; pistillate spikes $0.6-0.8 \mathrm{~cm}$ long vs. $0.7-1.5(3)$. Utricles of $C$. delongii are larger $(2.5-3 \mathrm{~mm})$ than those of C. minuta. A detailed comparison of the species is shown in Table.

Description. Perennial, $25-30 \mathrm{~cm}$ tall, forms loose tufts. Stems about $0.7-0.8 \mathrm{~mm}$ in diameter, smooth, striated; base of the stem wrapped in purplish-brown sheath. Leaves $1.2-2 \mathrm{~mm}$ wide, bright green, somewhat shorter than the stems. Inflorescence 3.3-5.5(6) $\mathrm{cm}$ long, with 3-4 spikes. Upper spike staminate, $(0.8) 1.2-1.5 \mathrm{~cm}$ long and $2 \mathrm{~mm}$ wide. Bottom 2-3 spikes pistillate, $0.6-0.8 \mathrm{~cm}$ long and $2 \mathrm{~mm}$ wide, on a peduncle $0.4-0.5 \mathrm{~cm}$ long. Bracts 3.5-4 cm long, leaf-like, without sheath, longer than the bottom spike but shorter than the whole inflorescence. Pistillate glumes $1.5 \mathrm{~mm}$ long. Utricles $2.5-3 \mathrm{~mm}$ long and $0.9-1 \mathrm{~mm}$ in diameter, with papillae, brownish at the top. Fruits $1.2 \mathrm{~mm}$ long. 


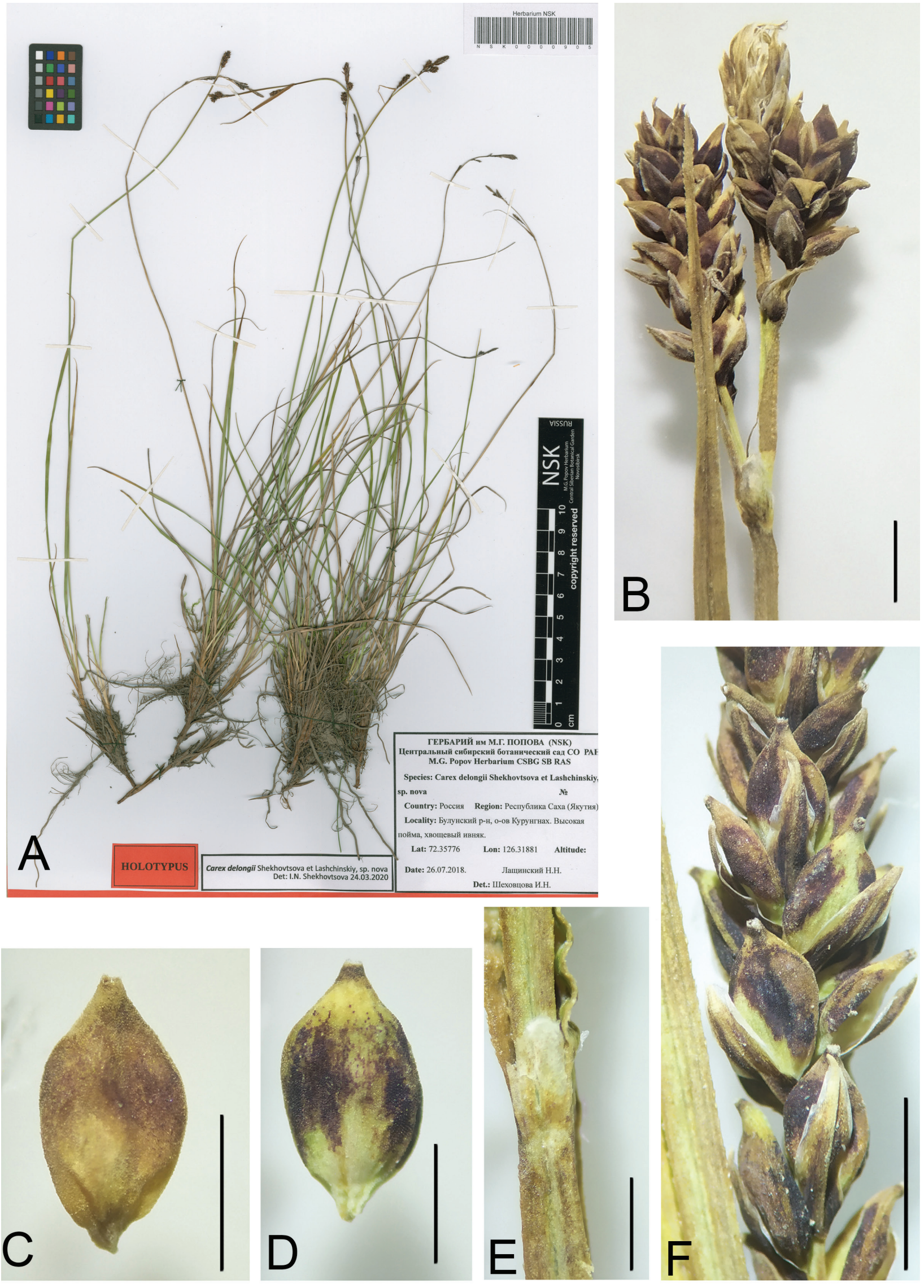

Fig. 1. Morphology of Carex delongii sp. nov. (from the holotype): A - holotype of Carex delongii sp. nov. (NSK0000905); B and F - pistillate spikes; C and D - utricles; E - leaf sheath. Scale bar - $2 \mathrm{~mm}$. 

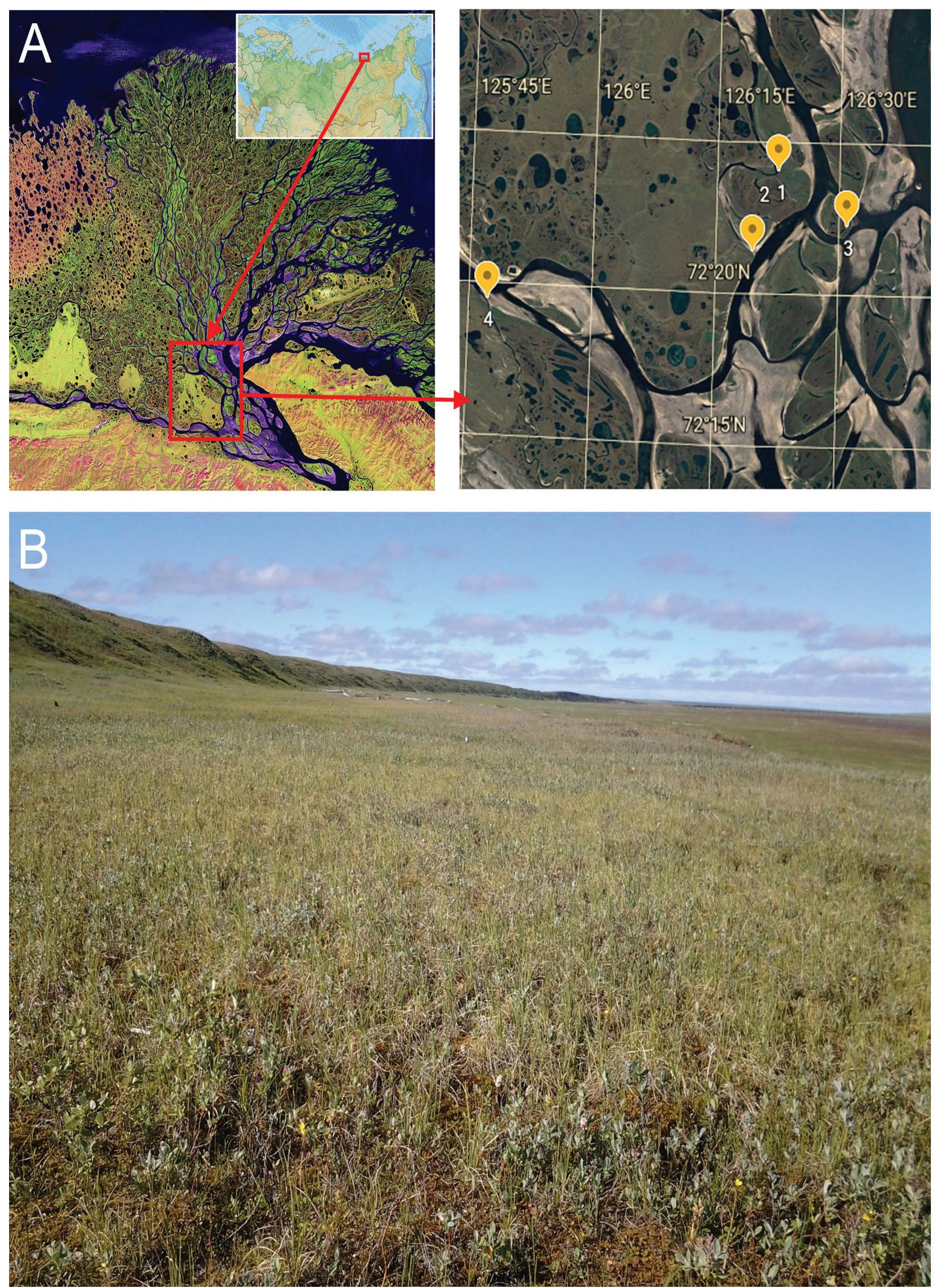

Fig. 2. Habitat and distribution Carex delongii sp. nov.: A - locations in the Lena River delta (NASA, 2000); B - classical habitat. 
Table

Diagnostic characters of Carex delongii sp. nov., C. cespitosa L., and C. minuta Franch.

\begin{tabular}{|c|c|c|c|}
\hline Character & C. delongii sp. nov. & C. cespitosa $\mathrm{L}$. & C. minuta Franch. \\
\hline Stems & $25-30 \mathrm{~cm}$ & up to $70 \mathrm{~cm}$ & up to $100 \mathrm{~cm}$ \\
\hline Leaves & $\begin{array}{l}1.2-1.5(2) \text { mm wide, bright } \\
\text { green, soft, shorter than stems }\end{array}$ & $\begin{array}{l}2-3 \mathrm{~mm} \text { wide, green or } \\
\text { greyish green, shorter } \\
\text { than stems or of similar } \\
\text { length }\end{array}$ & $\begin{array}{l}1-1.5 \mathrm{~mm} \text { wide, greyish green, } \\
\text { folded, shorter than stems or of } \\
\text { similar length }\end{array}$ \\
\hline Inflorescences & $\begin{array}{l}3.3-5.5(6) \mathrm{cm} \text { long, consist of } \\
3-4 \text { spikes; staminate spikes } \\
(0.8) 1.2-1.5 \mathrm{~cm} \text { long; bottom } 2-3 \\
\text { spikes pistillate } 0.6-0.8 \mathrm{~cm} \text { long, } \\
\text { the lowermost spike on a distance } \\
\text { to others }\end{array}$ & $\begin{array}{l}3-5 \mathrm{~cm} \text { long, consist of } \\
2-4 \text { adjacent spikes }\end{array}$ & $\begin{array}{l}\text { staminate spike } 1.5-4 \mathrm{~cm} \text { long; } \\
\text { bottom 2-3 spikes pistillate } \\
0.7-1.5(3) \mathrm{cm} \text { long }\end{array}$ \\
\hline Male glumes & light-colored & brown or reddish-brown & red or reddish-brown \\
\hline Female glumes & $\begin{array}{l}\text { brown, pointed, usually shorter } \\
\text { than utricles }\end{array}$ & $\begin{array}{l}\text { dark brown or brown, } \\
\text { usually shorter and } \\
\text { narrower than utricles }\end{array}$ & $\begin{array}{l}\text { almost black or reddish purple, } \\
\text { with a narrow light-colored } \\
\text { fringe, significantly shorter and } \\
\text { narrower than utricles }\end{array}$ \\
\hline Utricles & $\begin{array}{l}\text { with papillae, brownish, } \\
\text { oblong ovoid, } \\
2.5-3 \mathrm{~mm}\end{array}$ & $\begin{array}{l}\text { ovoid or elliptic, light } \\
\text { grey or greenish, } \\
2-3.5 \mathrm{~mm}\end{array}$ & $\begin{array}{l}\text { with papillae, oblong ovoid, } \\
1.8-2.2 \mathrm{~mm} \text {, greyish green, } \\
\text { without veins, small }\end{array}$ \\
\hline
\end{tabular}

Distribution. Distributed on the Arctic islands in the Lena River delta. (Fig. 2A).

All listed locations were restricted to annually flooded floodplain surface at two to three meters above the lowest river level (in mid-August) (Fig. 2B). The surface layer consisted of fine sand mixed with silt. The specimens grew at $20-80 \mathrm{~m}$ from the shoreline in pioneer plant communities. Vegetation covered 40 to $70 \%$ of the soil surface. Two main layers could be distinguished in community vertical structure: the shrub layer up to $60-80 \mathrm{~cm}$ high with projective coverage of 5 to $50 \%$ of the soil surface, and the herbaceous layer 20 to $40 \mathrm{~cm}$ high with 40 to $70 \%$ coverage. The shrub layer consists mainly of two widespread tundra Salix species: S. glauca L. and S. reptans Rupr., with a small admixture of riparian Salix species (S. alaxensis (Andersson) Coville and $S$. boganidensis Trautv.) and Duschekia fruticosa (Rupr.) Pouzar, which is on its northern limit (Nikolin et al., 2019). The dominant taxon in herbaceous layer is Equisetum arvense L. subsp. alpestre (Wahlenb.) Schönswetter et Elven, a common Arctic pioneer plant colonizing fresh alluvium along streams (Kholod, 2007). The number of vascular plant species varied from 14 to 26 per community with an average of 23 . Three main groups could be distinguished among the constant species:

(1) Riparian species indicating alluvial substrate and periodical flooding (Tanacetum bipinnatum
(L.) Sch. Bip., Cerastium regelii Ostenf., Stellaria humifusa Rottb.).

(2) Swamp species indicating water-saturated soil conditions (Pedicularis albolabiata (Hultén) Kozhevn., Cardamine pratensis L., Parnassia palustris L., Caltha radicans T. F. Forst.).

(3) Tundra species indicating zonal climate conditions (Calamagrostis holmii Lange, Bistorta vivipara (L.) Delarbe, Poa arctica R. Br.).

We should note the constant occurrence of Arctagrostis arundinacea (Trin.) Beal, a grass more typical in southern tundra, which occurred there near its northern limit.

Moss cover on the soil surface was thin and fragmented with total coverage below $30 \%$ and consisted of Bryum sp., Marchantia sp., and young specimens of Aulacomnium palustre (Hedw.) Schwägr. and Tomentypnum nitens (Hedw.) Loeske.

Thickness of the active layer measured in midAugust was significantly deeper in the studied habitats $(90-110 \mathrm{~cm})$ compared to tundra communities on the first terrace $(30-40 \mathrm{~cm})$. Based on the community structure and its floristic composition, the habitat of the new species could be described as a periodically flooded low floodplain in the tundra zone covered by fine alluvial sediments and occupied by pioneer vegetation on the initial stage of swamp formation. Deep active layer and the presence of species with more southern distribution (Duschekia fruticosa, 
Arctagrostis arundinacea) allowed us to assume that more findings of this species could be possible on floodplain habitats upstream of the studied area.

Etymology. The species was named after the American seafarer and Arctic explorer George Washington DeLong, who died in 1881 in the Lena River delta, very close to "locus classicus". DeLong's expedition was a tragic one, only twelve of its 32 members returned alive (De Long, 2018).

Comment. Neither C. cespitosa (Egorova, 1966, map 33, 1999; Malyshev, 1990, map 183) nor C. minuta (Malyshev, 1990, map 188; Egorova, 1999) were reported for the northern part of Yakutia, including the Lena River delta. However, C. minuta was listed in the "Conspectus florae of the Arctic Yakutia: Plantae vascular" (Egorova, 2016: 115) for the Tit-Ary Island. We did not examine this herbarium specimen, but its location and ecology suggest that it probably belongs to $C$. delongii.

\section{Molecular analysis}

The loci used for species barcoding and identification of sedges are known to have insufficient diversity and many sister species have identical DNA barcodes (Starr et al., 2009). The plastid matK gene fragment of $C$. delongii was found to be identical for a whole group of species in the section Phacocystis.

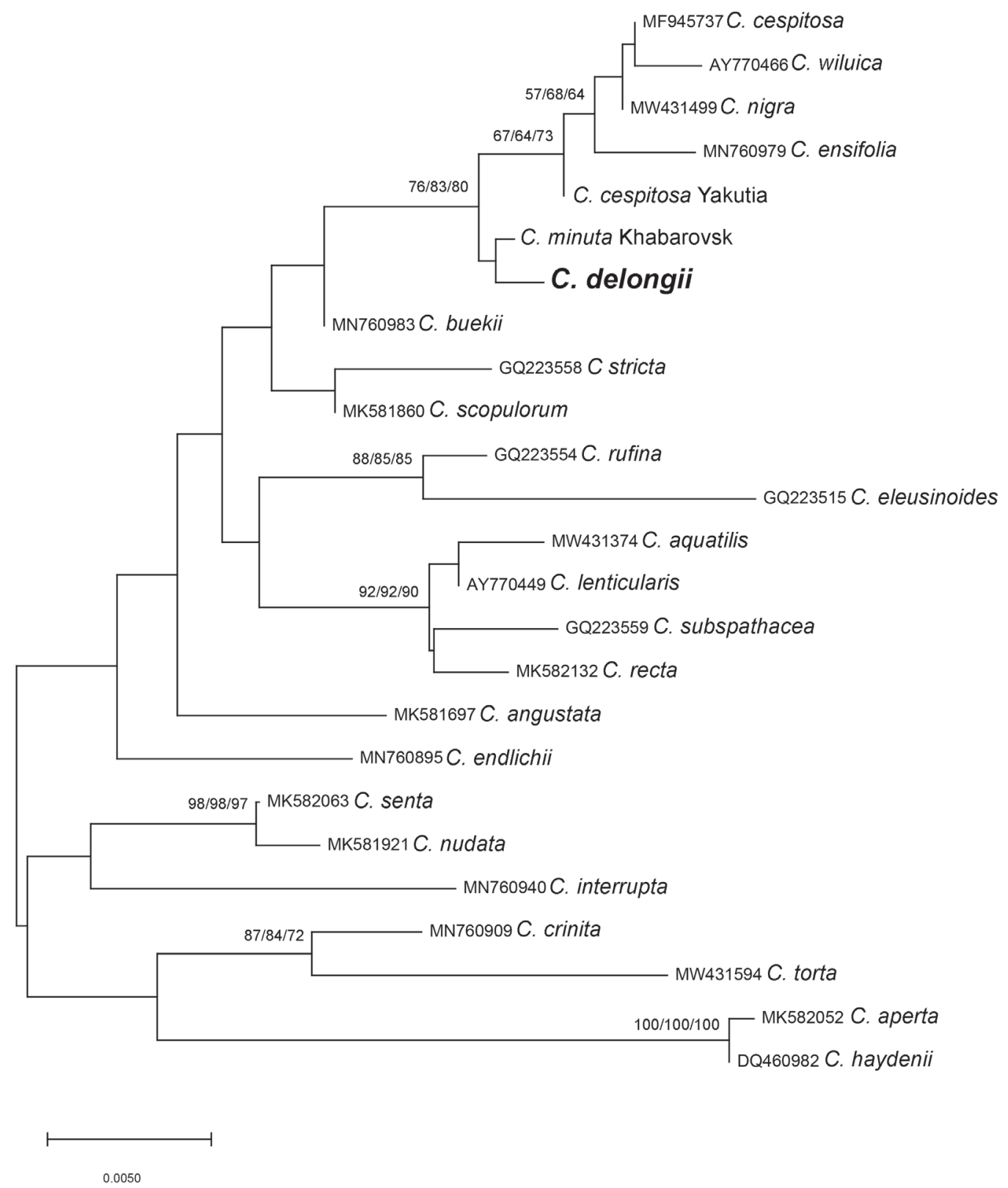

Fig. 3. Phylogenetic tree of the ETS sequences built using the ME algorithm. Number near branches indicate ME/MP/ ML bootstrap support. 
However, ETS demonstrated certain diversity. In addition to our sequences of $C$. cespitosa (MZ197172) and C. minuta (MZ197173) obtained in this study, we also compared $C$. delongii to a set of species of the section Phacocystis from the northern Palearctic (Fig. 3; since too many accessions were available, only one sequence per species is shown on the tree). One can see that $C$. delongii falls within a group comprising $C$. nigra (L.) Reichard, C. juncella (Fr.) Th. Fr. (C. wiluica Meinsh.), C. cespitosa, C. ensifolia Turcz. ex V. I. Krecz., and $C$. minuta. Within this group, $C$. delongii groups with a specimen of $C$. minuta from the Khabarovsk Territory (Russian Far East; MZ197173) also sequenced by us. The ETS sequence of this specimen differs from $C$. delongii by one nucleotide substitution and two degenerate positions (ETS is the part of the ribosomal cluster, which can consist of slightly divergent copies resulting in degenerate positions in the sequence). Genetic diversity within the section Phacocystis is low and many species have identical ETS sequences, so the fact that the ETS of C. delongii differs from those of closely related species is an evidence corroborating the hypothesis that it is a separate species.

\section{Acknowledgements}

This study was supported by Budget Projects no. AAAA-A21-121011290024-5 and no. 0259-20210010. Sanger sequencing was conducted on $3130 \mathrm{xl}$ DNA Analyzer (Applied Biosystems) in SB RAS Genomics Core Facility (ICBFM SB RAS, Novosibirsk, Russia). Scientific collections of the Central Siberian Botanical Garden SB RAS "Herbarium of vascular plants, lichens and fungi" (USU 440537, Herbarium NS, NSK) were used in the work.

\section{REFERENCES / ЛИTEPATУРA}

Benítez-Benítez C., Martín-Bravo S., Bjorå C. S., Gebauer S., Hipp A. L., Hoffmann M. H., Luceño M., Pedersen T M., Reznicek A., Roalson E., Volkova P., Yano O., Spalink D., Jiménez-Mejías P. 2021. Geographical vs. ecological diversification patterns in Carex sect. Phacocystis (Cyperaceae): patterns hidden behind a twisted taxonomy. J. Syst. Evol. 59(4): 642-667. DOI: 10.1111/jse.12731

De Long G. W. 2018. The Voyage of the Jeannette. Moscow: Paulsen Publishing House. 464 pp.

Egorova A. A. 2016. Conspectus florae of the Arctic Yakutia: Plantae vascular. Novosibirsk: Nauka. 188 pp. [In Russian] (Ezорова A. A. Конспект флоры Арктической Якутии: сосудистые растения. Новосибирск: Наука, 2016. 188 c.).

Egorova T. V. 1966. Carex L. In: Arkticheskaya flora SSSR [Flora of the Russian Arctic]. Vol. 3. Cyperaceae. Moscow; Leningrad: Nauka. 176 pp. [In Russian] (Егорова T. В. Сarex L. // Арктическая флора СССР. Вып. 3. Суреraceae. М.; Л.: Наука, 1966. 176 с.).

Egorova T. V. 1999. The sedges (Carex L.) of Russia and adjacent states (within the limits of the former USSR). St.-Petersburg: St.-Petersburg State Chemical-Pharmaceutical Academy; St. Louis: Missoury Botanical Garden Press. 772 pp. [In Russian and English] (Eгорова T. В. Осоки (Сагех L.) России и сопредельных государств (в пределах бывшего СССР). СПб.: Санкт-Петербургская гос. хим.-фарм. акад.; Сент-Луис: Миссурийский бот. сад, 1999. 772 c.).

Govaerts R., Jiménez-Mejías P., Koopman J., Simpson D., Goetghebeur P., Wilson K., Egorova T., Bruhl J. 2020. World checklist of Cyperaceae. Kew: Facilitated by the Royal Botanic Gardens. URL: http://wcsp.science.kew. org (Accessed May 2020).

Hultén E. 1968. Flora of Alaska and neighboring territories: a manual of the vascular plants. Stanford: Stanford University Press. 1008 pp.

Kholod S. S. 2007. Classification of Wrangel Island vegetation. Vegetation of Russia 11: 3-135. [In Russian] (Xoлод С. С. Классификация растительности острова Врангеля // Растительность России, 2007. № 11. С. 3-135). DOI: $10.31111 /$ vegrus/2007.11.3

Kumar S., Stecher G., Li M., Knyaz C., Tamura K. 2018. MEGA X: molecular evolutionary genetics analysis across computing platforms. Molec. Biol. Evol. 35(6): 1547. DOI: 10.1093/molbev/msy096

Malyschev L. I. 1990. Carex L. In: Flora of Siberia. Vol. 3. Cyperaceae. Novosibirsk: Nauka. Pp. 35-170. [In Russian] (Малышев Л. И. Сагех L. - Осока // Флора Сибири. Т. 3. Суреraceae. Новосибирск: Наука, 1990. C. 35-170).

NASA Landsat Programme. 2000. Lena Delta in Landsat 7/ETM+, Visible Earth, v1 ID: 407 18024. URL: https:// earthobservatory.nasa.gov/images/2704/lena-river-delta?src=ve (Last acccessed 9 December 2021).

Nikolin E. G., Yakshina I. A., Lashchinskiy N. N. 2019. Distribution of few wooden species on their northern limit in Ust'Lenskiy natural reserve (Yakutia). Report II. Duschekia fruticosa (Rupr.) Pouzar. Siberian Forest J. 2: $32-44$. [In Russian] (Николин Е. Г., Якиина И. А., Лащинский Н. Н. Распространение некоторых древесных видов 
на северном пределе в Усть-Ленском заповеднике (Якутия). Сообщение II. Душекия кустарниковая Duschekia fruticosa (Rupr.) Pouzar // Сибирский лесной журн., 2019. № 2. С. 32-44). DOI: 10.15372/SJFS20190203

Shekhovtsov S. V., Shekhovtsova I. N., Peltek S. E. 2012. Phylogeny of Siberian species of Carex sect. Vesicariae based on nuclear and plastid markers. Nord. J. Bot. 30(3): 343-351. DOI: 10.1111/j.1756-1051.2011.01405.x

Shekhovtsova I. N. 2012. Carex L. In: Konspekt flory Aziatskoy Rossii: Sosudistyye rasteniya [Checklist of the flora of Asian Russia: Vascular plants]. Novosibirsk: Publ. SB RAS. Pp. 479-505. [In Russian] (Шеховцова И. Н. Carex L. // Конспект флоры Азиатской России: Сосудистые растения. Новосибирск: Изд-во СО РАН, 2012. С. 479-505).

Stamatakis A. 2014. RAxML version 8: a tool for phylogenetic analysis and post-analysis of large phylogenies. Bioinformatics 30(9): 1312-1313. DOI: 10.1093/bioinformatics/btu033

Standley L. A., Cayouette J., Bruederle L. 2002. Carex Linnaeus sect. Phacocystis Dumortier. In: Flora of North America. Vol. 23. New York: N. Y. University Press. Pp. 379-401.

Starr J. R., Harris S. A., Simpson D. A. 2003. Potential of the 5' and 3' ends of the intergenic spacer (IGS) of rDNA in the Cyperaceae: New sequences for lower-level phylogenies in sedges with an example from Uncinia Pers. Int. J. Pl. Sci. 164(2): 213-227. DOI: 10.1086/346168

Starr J. R., Naczi R. F., Chouinard B. N. 2009. Plant DNA barcodes and species resolution in sedges (Carex, Cyperaceae). Mol. Ecol. Resour. 9: 151-163. DOI: 10.1111/j.1755-0998.2009.02640.x 